\title{
Firmness Decline in 'Gala' Apple during Fruit Development
}

\author{
Richard K.Volz ${ }^{1}$ \\ The Horticultural and Food Research Institute of New Zealand, Hawkes Bay Research Centre, Private \\ Bag 1401, Havelock North, New Zealand
}

F. Roger Harker

The Horticultural and Food Research Institute of New Zealand, Mt. Albert Research Center, Private Bag 92169, Auckland, New Zealand

\begin{abstract}
Sandy Lang
The Horticultural and Food Research Institute of New Zealand, Palmerston North Research Centre, Private Bag 11030, Palmerston North, New Zealand
\end{abstract}

Additional index words. Malus sylvestris, texture, puncture, tissue anatomy, intercellular air space, cell volume, cell packing density, compression, shear

\begin{abstract}
Puncture force was measured in 'Gala' apple [Malus sylvestris (L.) Mill. var. domestica (Borkh.) Mansf.] fruit from 16 to 175 days after full bloom over 2 years using a range of circular flat-tipped probes ( 1 to $11 \mathrm{~mm}$ diameter) to test the firmness of each fruit. The area-dependent $\left(K_{\mathrm{a}}\right)$ and perimeter-dependent $\left(K_{\mathrm{p}}\right)$ coefficients of puncture force were determined and were used to calculate the indicative puncture force approximating a standard 11.1-mm-diameter Effegi/Magness-Taylor probe for even the smallest fruit. $K_{\mathrm{a}}$ declined exponentially throughout fruit development with much greater changes occurring closer to bloom. In contrast, maximum $K_{p}$ occurred at 107 to 119 days after full bloom before declining progressively. Estimated firmness (using a 11.1-mm-diameter probe) declined constantly from 16 days after full bloom. $K_{\mathrm{a}} \mathbf{w a s}_{\text {associated }}$ with developmental changes in cortical tissue intercellular air space, cell volume and cell packing density although relationships changed throughout fruit growth. However seasonal change in $K_{p}$ was not associated with any obvious anatomical change in the cortex.
\end{abstract}

Texture is a key driver of consumer preferences for apples [Malus sylvestris (L.) Mill. var. domestica (Borkh.) Mansf.] (Dailliant-Spinnler et al., 1996; Jaeger et al., 1998), and the instrumental puncture test is a good predictor of the sensory texture attributes crispness, hardness, and juiciness (Harker et al., 2002a; 2002b) as well as consumer acceptability (Liu and King, 1978). For this reason the simple puncture test, as practiced using a penetrometer, is used in quality standards (Harker et al., 1997) and as a research tool (Harker et al., 2002b).

Most research effort devoted to understanding texture change in relation to concurrent changes in tissue structure, composition, and physiological condition has been concerned with ripeningmediated fruit softening (DeEll et al., 2001; Harker et al., 1997, 2000; Sams, 1999). Many of the properties of the individual cortical cell, its constituent parts and its relationship with its neighbors are determined well before ripening begins. However little is known of the textural changes that occur earlier during fruit growth. Practically, such knowledge may better allow apple producers to manipulate growing practices to optimize texture, to improve preharvest predictions of final fruit texture as well as for breeders to better develop improved and novel textural characteristics in new cultivars.

The strength of fruit tissues is a function of the mechanical properties of the cell walls, the presence of intercellular fluid that provides support to the cell structure, the strength of cell-to-cell bonding at the middle lamella, and the area of cell-to-cell contact (Harker et al., 1997). Furthermore, the mechanical properties of

Received for publication 30 Dec. 2002. Accepted for publication 30 June 2003. We thank Murray Oliver and Georgina Milne for technical assistance, Nihal DeSilva for statistical advice and Alistair Hall and Ian Hallet for helpful comments in the preparation of this manuscript

1To whom reprint requests should be addressed; e-mail rvolz@hortresearch.co.nz. the cell walls may vary in response to changes in turgor (De Belie et al., 2000). Any or all of these factors may change during fruit growth and development. However, the marked changes in cell size, shape, and packing are compelling and well documented (Bain and Robertson, 1951; Bollard, 1970; Pratt, 1988; Skene, 1966; Smith, 1950). Fruit weight in apple increases expolinearly during development (Lakso et al., 1995) with most rapid rate of mass increase occurring 20 to $50 \mathrm{~d}$ after bloom (DAFB). This coincides with the highest rates of increase in parenchymal cell volume (CV) and cortical intercellular air space (IS). This is followed by a linear increase in CV but progressively smaller increases in IS. These developmental changes during fruit expansion lead to reductions in gross cell wall content per fixed volume of tissue (Harker and Ferguson, 1988). Furthermore, changes in cell packing density (inversely related to tissue air space) are of particular interest because positive relationships with texture have been found in earlier studies with mature apples (King et al., 2001; Vincent, 1989). Thus, close relationships between puncture force and IS, CV and cell packing density are anticipated during fruit development. The main objectives of this study were therefore to characterize changes in puncture force during apple fruit development, and to examine relationships between cellular measurements and firmness.

\section{Materials and Methods}

Trees. Four 'Gala' trees on M.M. 106 rootstock planted in 1996 and located at the HortResearch orchard in Hawkes Bay, New Zealand were chosen for the experiment. These trees were guard trees in an outside row of a semi-dwarfing rootstock trial, and were of similar vigor and size.

EXPERIMENTAL.In 2000, 100 flowering spurs per tree were tagged 
at full bloom (14 to 16 Oct. 2000) and all flowers except one lateral flower removed. These flowers were immediately pollinated with dry 'Granny Smith' pollen, collected during the previous day. Spurs were located on 2 to 4 year-old wood located in the outer zone of the tree canopy 1 to $2 \mathrm{~m}$ from the ground. Eight tagged fruit per tree (32 fruit total) were randomly collected on nine occasions at 12 to $22 \mathrm{~d}$ intervals during fruit development and ripening until 153 DAFB. Sample collections were terminated after the cessation of the commercial harvest period on 15 Mar. In 2001 , fruit were sampled from similar spurs and positions within the trees but supplemental hand pollination was not carried out. Four fruit per tagged tree (16 fruit total) were sampled randomly at 11 to $15 \mathrm{~d}$ intervals from 79 DAFB to 175 DAFB (full bloom $=1$ Oct.). Trees were thinned to a commercial crop load on 10 Dec. (2000) or 15 Dec. (2001). Otherwise trees were managed according to standard commercial practice with no other picking carried out on the trees.

Firmness MEASUREMENTS. On each sampling date, fresh weight of each fruit was measured using a Mettler balance $( \pm 0.01 \mathrm{~g})$. On each of 16 fruit (four fruit per tree) four radial puncture measurements were made approximately equidistant around the equator. Each measurement used a different diameter probe, and the skin was pared from the sites before puncturing. A balanced complete block design was used to assign quadrants (blushed, shaded and two adjacent sides) and the order in which different probes were used. In this way any bias due to position of fruit quarter and the order of probe puncture application into each fruit was removed. Punctures were made using a circular flat-head steel probes (1 to $11 \mathrm{~mm}$ in diameter) inserted into materials testing machine (model MN44; Instron, Canton, Mass.) equipped with a $50 \mathrm{~N}$ (16 to 44 DAFB sampling dates) or $500 \mathrm{~N}$ load cell ( $\geq 58 \mathrm{DAFB}$ ). Probes traveled downwards into the fruit at $240 \mathrm{~mm} \cdot \mathrm{min}^{-1}$. At each sampling date, the largest probe chosen was that which did not crack the fruit on entering (Table 1) and, from 80 DAFB, the smallest probe was $3 \mathrm{~mm}$ in diameter, based on recommendations by Bourne (1975). Puncture depths varied from 2 (16 DAFB), 5 (30 DAFB) to $8 \mathrm{~mm}$ after 30 DAFB. Force-deformation curves were evaluated for each measurement and puncture (bioyield) force recorded, usually at the peak of the force-distance curve.

MATURITy. Maturity assessments were carried out on fruit beginning 92 DAFB (2000) and 105 DAFB (2001). Fruit were scored for background color $(1=$ light green, $10=$ dark gold $)$. Internal ethylene concentrations were determined by withdrawing a 1-mL core cavity gas sample from the core of each fruit and injecting into a gas chromatograph (model GC8A; Shimadzu, Columbia, Md.). Starch pattern index was determined by dipping half fruit in iodine/potassium iodide for $1 \mathrm{~min}$ and scored using the ENZA New Zealand standard starch pattern index chart for apples $(0=100 \%$ starch, $6=0 \%$ starch $)$.

Tissue ANATOMICAL MEASUREMENTS. Cortical cellular dimensions and fractional IS (except at 16 DAFB for IS) were determined on each of the second group of 16 fruit sampled in 2000.

Table 1. Probe diameters used to measure firmness of 'Gala' apple fruit at various dates after full bloom (DAFB).

\begin{tabular}{lc}
$\begin{array}{l}\text { Sampling date } \\
(\mathrm{DAFB})\end{array}$ & $\begin{array}{c}\text { Probe diam } \\
(\mathrm{mm})\end{array}$ \\
\hline 16 & $1.0,1.5,2.0,2.5$ \\
30 & $2.0,2.5,3.0,3.5$ \\
44 & $2,3,4,5$ \\
58 & $3,5,6,8$ \\
$\geq 80$ & $3,5,8,11$ \\
\hline
\end{tabular}

Each fruit was cut in half transversely and cortical tissue blocks removed beginning immediately below (16 to $44 \mathrm{DAFB}$ ) or 3 $\mathrm{mm}$ (from $58 \mathrm{DAFB}$ ) beneath the skin. Three blocks per fruit (4 $\times 4 \times 4 \mathrm{~mm}$ at 30 and $44 \mathrm{DAFB})$ or one block per fruit $(8 \times 8 \times$ $4 \mathrm{~mm}$ at 58 DAFB or $10 \times 10 \times 10 \mathrm{~mm}$ from 80 DAFB) were taken for IS measurements. One additional block from each fruit was taken for cell dimensions such that the largest face was in the longitudinal plane $(4 \times 3 \times 1 \mathrm{~mm}$ at 16 to 58 DAFB and $10 \times 8 \times$ $3 \mathrm{~mm}$ from $80 \mathrm{DAFB})$. Tissue sampling was carried out such that the four fruit from each tree had tissue blocks removed from four different sides (blushed, non-blushed and the two other sides).

Determinations of IS and cell dimensions were carried out following the methods described in Drazeta (2002). Briefly, IS was estimated by measured volume displacement of the submerged tissue blocks before and after vacuum infiltration with water. For cell dimensions, the two diameters of each of 20 random clearly visible cells from each block in the longitudinal radial plane were measured using a conventional light microscope and a video-camera system. The first diameter $\left(d_{1}\right)$ was always made along the longer (primary) axis of the cell with the second measurement $\left(d_{2}\right)$ orthogonal to this. 'Gala' parenchymal cells are approximately prolate spheroids with $d_{1}$ lying in the radial plane and the shortest diameter in the tangential plane, this shape being maintained throughout development (data not shown). For this cell shape, the calculation of $\mathrm{CV}$ assumed that the third cell diameter $\left(d_{3}\right)$ equalled $d_{2}$ and followed the formula below

$$
C V=\frac{\pi \cdot\left(d_{1} \cdot d_{2} \cdot d_{3}\right)}{6}
$$

However as the cells were not perfectly aligned and were pointing slightly upward, downward or sideway, the longer cell diameter $d_{1}$ was underestimated slightly. We assumed that the orientations of cells in the radial direction followed a Fisher distribution, which approximates a normal distribution but for angles (Weibel, 1980). We were then able to estimate from observations of sections in all three planes (unpublished data) that the true aspect ratio of the cells is on average $7 \%$ greater than aspect ratios viewed in the longitudinal radial plane. $\mathrm{CVs}$, estimated using Eq. [1], were increased accordingly. Cell cortical packing density (cell number per $\mathrm{mm}^{3}$ tissue) was subsequently calculated for each fruit by dividing the volume of one $\mathrm{mm}^{3}$ occupied only by cells (i.e., excluding proportion occupied by IS), by the fruit's mean CV (Goffinet et al., 1995).

CALCULATION OF COMPRESSION AND SHEAR FORCES. The puncture force for a flat-tipped probe can be resolved into area-dependent (compression force) and perimeter-dependent (shear force) components using the following formula:

$F=K_{a} \cdot A+K_{p} \cdot P+C$

which can be rearranged to

$\frac{F}{A}=K_{a}+\frac{4 \cdot K_{p}}{d}+\frac{4 \cdot C}{\pi \cdot d^{2}}$

or

$\frac{F}{P}=K_{p}+\frac{d \cdot K_{a}}{4}+\frac{C}{\pi \cdot d}$

where $K_{a}$ and $K_{p}$ are the probe cross-sectional area (compression) and perimeter (shear) coefficients, $\mathrm{A}$ is the probe cross-sectional area, $\mathrm{P}$ is the probe perimeter, $d=$ probe diameter and $C$ is a constant, that Bourne (1975) estimated to be zero. 
Hence, the puncture force per unit area is a hyperbolic function of probe diameter $(d)$ where $4 K_{p}$ is the slope inEq. [3], and puncture force per unit perimeter length is a linear function of $d$ where $K_{a} / 4$ is the slope in Eq. [4]. Alternatively, $\mathrm{K}_{\mathrm{a}}$ and $\mathrm{K}_{\mathrm{p}}$ can also be estimated from Eqs. [3] and [4] by calculating the intercepts for the plots (Bourne, 1966). In the present study $K_{a}$ and $K_{p}$ were determined using both methods, but data are only presented using the former.

Statistical analysis. The SAS Generalized Linear Model Procedure (SAS Institute, 1997) was used to quantify the relationships F/A and F/P with 1/d and d respectively, and to determine how this relationship varied with sampling date.

\section{Results}

Fruit DEVELOPMENTAL CHANGES. In 2000, fruit weight increased expolinearly up to 120 DAFB before slightly slowing during the following $33 \mathrm{~d}$ (Fig. 1A). Fruit were slightly smaller in 2001 but generally followed a similar pattern during the mid-late season measurement period. Fruit in 2001 matured later than those in 2000 as indicated by the delay in the onset of the ethylene climacteric (Fig. 1A), and a delay in starch hydrolysis and skin degreening (data not shown).

IS increased rapidly and linearly in fruit from 30 to 58 DAFB of the 2000 season (Fig. 1B). This represented the period of exponential fruit growth, and all subsequent increases in IS were much smaller. CV also increased rapidly from 30 to 58 DAFB but in contrast to IS, continued to increase expolinearly up to 107 DAFB before slowing slightly (Fig. 1B). Cell packing density (cells $/ \mathrm{mm}^{3}$; Fig. 1B) estimates declined curvilinearly, with rate decreasing progressively during the season as IS and CV occupied a greater proportion of the cortical tissue.
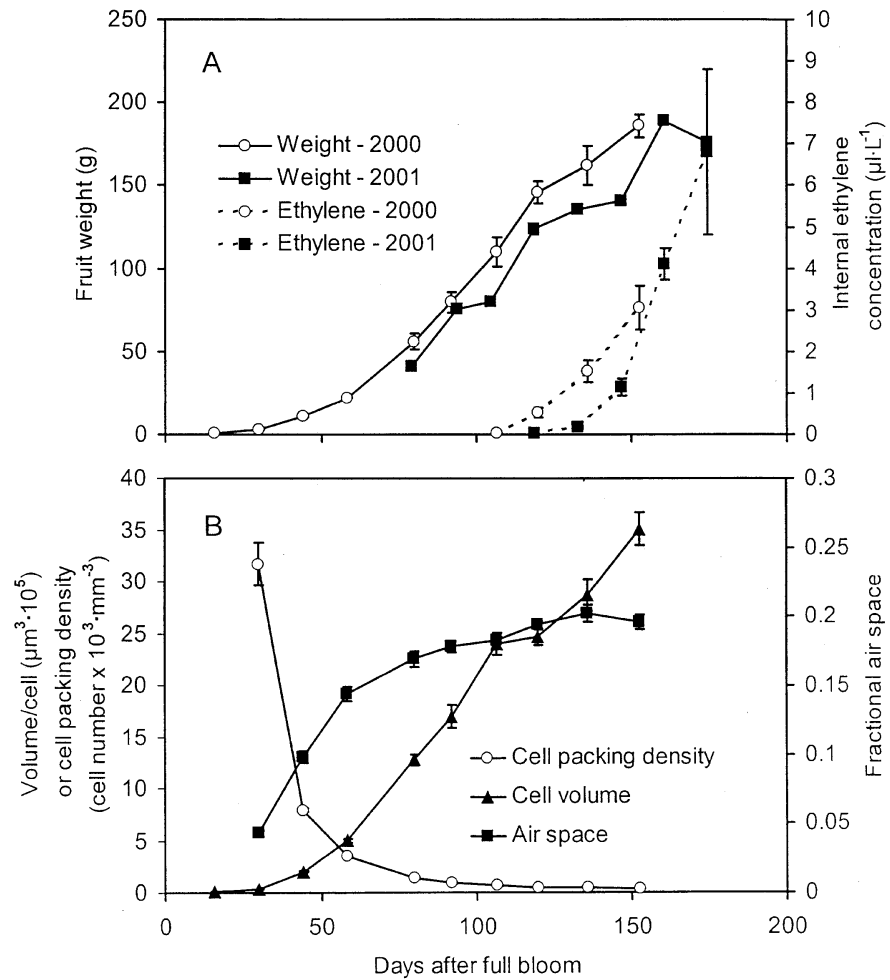

Fig. 1. Changes in (A) fruit weight and internal ethylene concentration in 2000 and 2001 and (B) cortical tissue characteristics in 2000 for 'Gala' apple. Bars $= \pm$ standard error.
Textural Changes. Force-distance curves generated during puncture tests were typical of those in the literature (Abbott et al., 1982, 1984; Bourne, 1965). As the probe was driven through the fruit cortex, force increased linearly up to a maximum (bioyield) before exhibiting a marked drop in force, which was followed by a period where the force remained constant or gradually increased (Fig. 2). Upon the puncturing of some small fruit ( $\leq 44 \mathrm{DAFB})$ with 2 to $5 \mathrm{~mm}$ diameter probes, a premature bioyield point was observed (usually 0.2 to $1.4 \mathrm{~mm}$ from first tissue contact; Fig. $2 \mathrm{~A})$. This may be interpreted as a whole fruit phenomenon rather than representing a characteristic of tissue resistance to puncture. For instance, the skin can have a major influence in determining energy absorbed by apples before they crack during whole fruit compression, as elucidated by Kahn in 1989 (see Vincent, 1990 p.265). From 58 DAFB onward in 2000 and in 2001 we did not observe these premature bioyield points.

All probes exhibited good relationships between diameter and force (data not shown). A3-mm-diameter probe was used from 30 DAFB until the end of commercial harvest, and provided the most prolonged dataset for a single probe (Fig. 3). Puncture force for the $3 \mathrm{~mm}$ diameter probe declined in a triphasic pattern throughout apple fruit growth. There was a rapid decline in firmness from 30 to 80 DAFB followed by a period of little change for the following $27 \mathrm{~d}$ followed by another more rapid decline during late season development. A similar pattern was observed during the mid-late season period in 2001. The general pattern of firmness
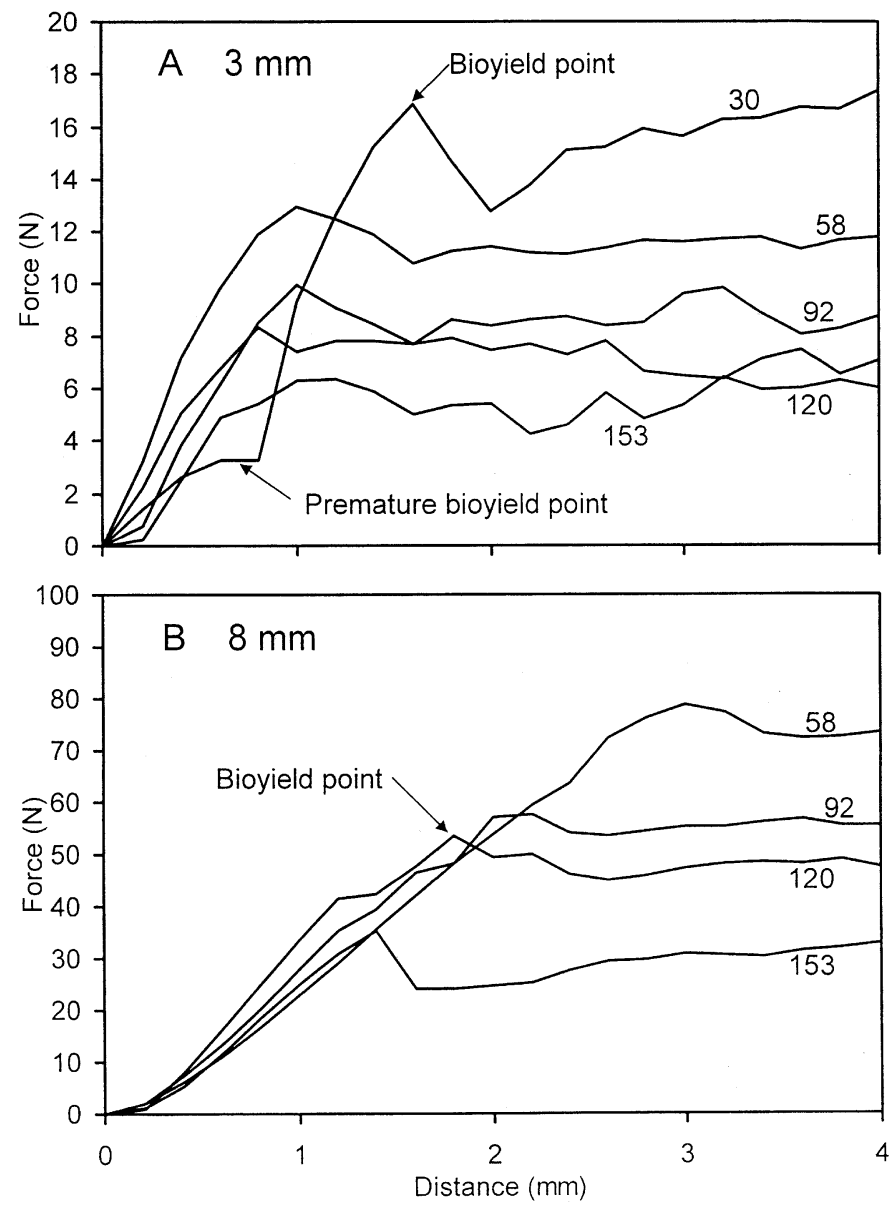

Fig. 2. Typical force $\mathrm{x}$ distance curves for (A) 3-mm and (B) 8-mm probe diameters, for 'Gala' apple fruit harvested at different DAFB during fruit development (2000). Puncture (bioyield) force indicated by arrow. 

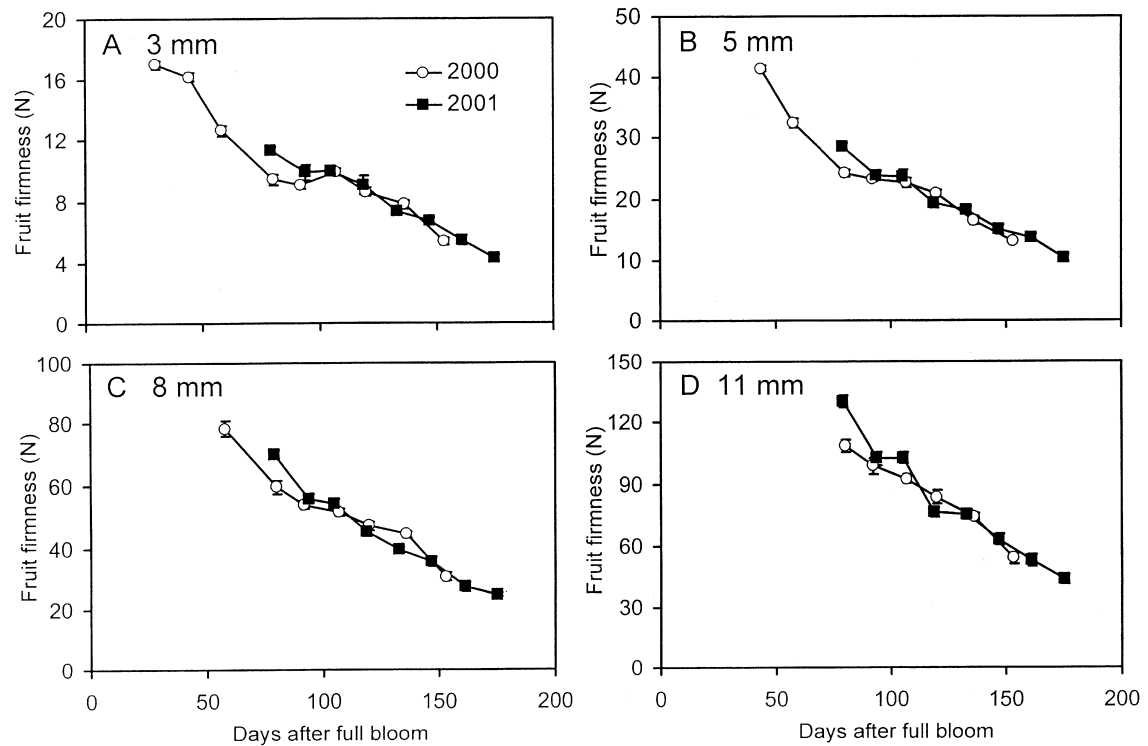

maturation. However when $\mathrm{K}_{\mathrm{p}}$ was estimated from Eq. [4], this change was not significant in both years $(P=0.08$ to 0.10$)$.

Using the estimates of $\mathrm{K}_{\mathrm{p}}$ and $\mathrm{K}_{\mathrm{a}}$ derived from Eq. [3], we were able to calculate the theoretical seasonal change in fracture force for an 11.1-mm probe beginning from 16 DAFB (Fig. 5). The 11.1-mm-diameter probe is the size of a conventional Effegi or Magness Taylor probe (7/16-inch), although it has a flat rather than a convex tip. Thus, the values presented in Fig. 5 relate closely to standard industry measurements. Compression force contributed the most to the total estimated firmness throughout development and generally the pattern of puncture force for the $11.1 \mathrm{~mm}$ probe followed that of $\mathrm{K}_{\mathrm{a}}$ (Fig. 4A). While at fruit maturity compression force still dominated, shear force made up a significant proportion (10\% to $15 \%$ ) of

Fig. 3. Changes in fracture force during fruit development for four probe diameters in each of 2 years for 'Gala' apple. Bars $= \pm$ standard error.

decline throughout the season also extended to the larger probes. However, as the probe diameter increased the significance of the mid-season plateau became less, such that for the $11 \mathrm{~mm}$ probe, firmness declined linearly from 80 DAFB until the final harvest in both years (Fig. 3). Similar patterns were found when firmness data was plotted against fruit weight (data not shown).

The validity of the assumption that $\mathrm{C}$ is zero in Eqs. [3] and [4] was tested by inserting the term $1 / \mathrm{d}^{2}$ (Eq. [3] or 1/d (Eq. [4]) as an additional independent variable into the GLM procedure in SAS. C was not significantly different from zero for estimates based on Eq. [4] ( $P>0.05$ in both years), Eq. [3] in 2001 ( $P=$ $0.66)$ or when probes with diameters of $2.0 \mathrm{~mm}$ or greater were considered in $2000(P=0.12)$. In 2000, intercepts derived from Eq. [3] for the two smallest probes (1.0 and $1.5 \mathrm{~mm}$ diameter) deviated from those found for the larger probes at the same sampling time, and, when data from these smallest probes were included in the analysis, $\mathrm{C}$ was significantly different from zero for this equation $(P=0.02$; data not shown). This confirms the suggestion of Bourne (1975) that $\mathrm{K}_{\mathrm{a}}$ and $\mathrm{K}_{\mathrm{p}}$ derived from probes smaller than $2 \mathrm{~mm}$ diameter could be unreliable. However, only fruit harvested at 16 DAFB in 2000 were tested with 1.0 and 1.5 mm diameter probes (Table 1). Thus, while estimates for $\mathrm{K}_{\mathrm{a}}$ and $\mathrm{K}_{\mathrm{p}}$ for fruit harvested at 16 DAFB should be interpreted with a level of caution, those for fruit harvested 30 DAFB onward are strong.

$\mathrm{K}_{\mathrm{a}}$ derived from each equation (intercept in Eq. [3], Fig 4A and slope in Eq. [4], data not shown) declined exponentially ( $P$ $<0.001$ ) with advancing sampling date in 2000 and 2001, with slower decline occurring later during fruit development. However there was no difference in the rate of $\mathrm{K}_{\mathrm{a}}$ decline between the two years $(P=0.25) . \mathrm{K}_{\mathrm{a}}$ estimates from each equation averaged just $3 \%$ and only as high as $9 \%$ difference throughout fruit development (data not shown) in both 2000 and 2001. This also supports the assumption that $\mathrm{C}$ is likely to be extremely small in apple fruit.

When estimated using Eq. [3], $\mathrm{K}_{\mathrm{p}}$ also changed $(P<0.001)$ throughout development, with similar patterns noted in both years (Fig. 4B). It increased immediately after anthesis and declined slightly until another major increase peaking at 107 DAFB (2000) or 119 DAFB (2001), then declined steadily throughout fruit the total puncture force.

The time series of $K_{a}$ in 2000 was strongly correlated with the time series of IS and CV $(r=-0.94$ to $-0.96, P<0.001)$ but less so with that of cell number $/ \mathrm{mm}^{3}(r=0.72, P=0.04)$. Larger changes in cell packing and IS (Fig. 6) and smaller changes in CV relative to $\mathrm{K}_{\mathrm{a}}$ occurred during early fruit growth compared with
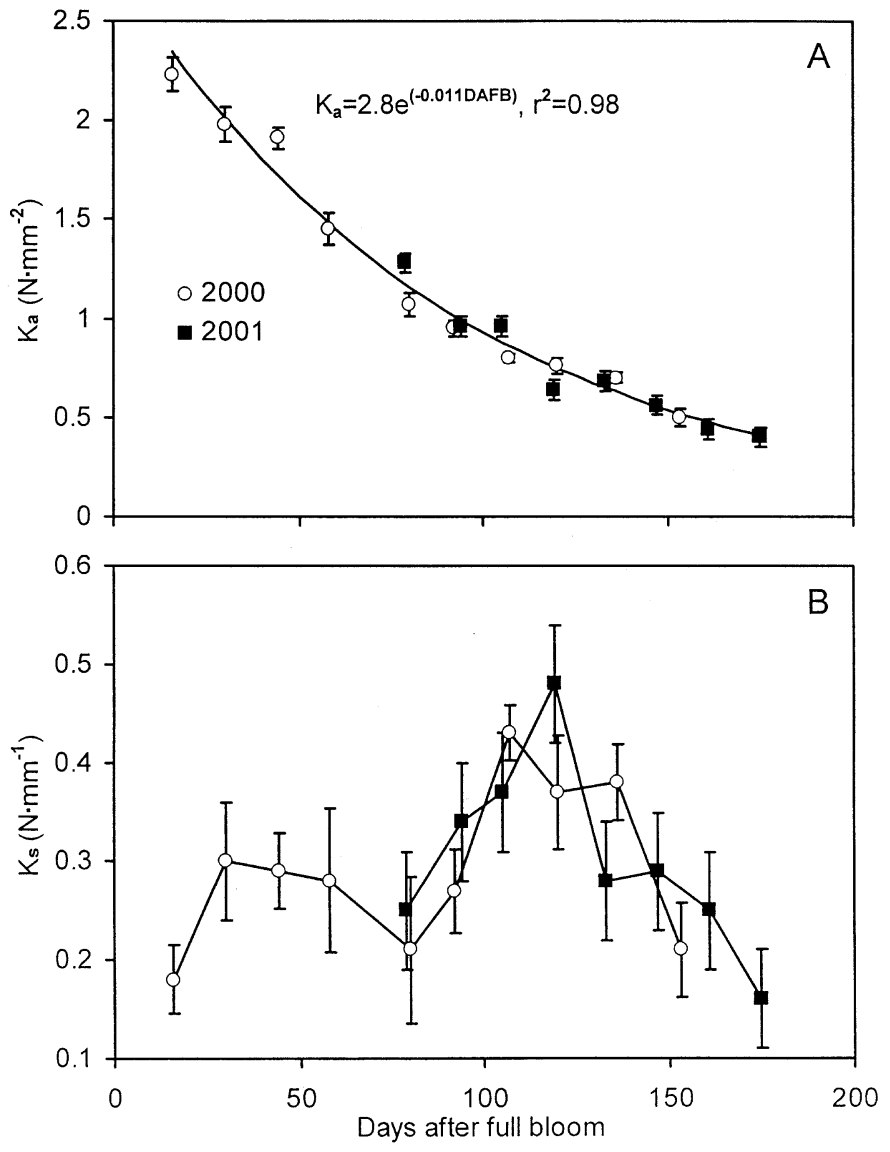

Fig. 4. Changes in (A) $K_{a}$ (area - dependent coefficient) and (B) $K_{p}$ (perimeter -dependent coefficient) during fruit development in each of 2 years for 'Gala' apple. For $\mathbf{A}$ the best-fit curve is for data pooled over both years. Estimates derived from Eq. [3]. Bars $= \pm$ standard error. 
relative changes that occurred later in development. Changes in $\mathrm{K}_{\mathrm{p}}$ showed no significant relationship with any of the anatomical characteristics measured.

\section{Discussion}

It is well known that apple fruit soften during the period of maturation that occurs just before commercial harvest (Knee and Smith, 1989; Lau, 1985; Watkins et al., 1993). In this study we have established that softening commences much earlier than this. Indeed, fruit softening was detected as soon as it was practicable to measure texture (16 DAFB) and continued throughout fruit development. From a physiological perspective, the study thus identifies two factors that can have a major impact on fruit texture. These are the mechanical properties of the flesh that are established at or soon after anthesis, and the rate of softening during fruit growth and development. Both of these factors are likely to be under genetic and environmental control.

$\mathrm{K}_{\mathrm{p}}$ followed a general trend suggesting that tissue resistance to shear increases during the middle period of fruit development and then declines towards the end of development (Fig. 4B). It is likely that these changes in $\mathrm{K}_{\mathrm{p}}$ reflect changes in the shear strength of the cell walls, since cell-to-cell debonding is not a dominant cause of tissue failure in apple fruit firmer than $\approx 60 \mathrm{~N}$ (puncture force with a 11.1-mm-diameter probe; Harker et al., 2002b). The reduction in the shear strength seems to be initiated at the start of the maturation phase of fruit development-indicated by the increase in the internal ethylene concentration (Fig. 4B cf. Fig. 1A). The most profound indication of the effect of $K_{p}$ on puncture force was observed with the 3-mm-diameter probe. With smaller probes the influence of perimeter effects relative to area effects are much greater than for the large diameter probes. Thus, the increase in $\mathrm{K}_{\mathrm{p}}$ that occurred from 80 to $110 \mathrm{DAFB}$ was able to counteract the decline in $\mathrm{K}_{\mathrm{a}}$ so that puncture force remained constant during that period (3-mm-probe, 80 to 110 DAFB, Fig. 3).

Assuming that $\mathrm{K}_{\mathrm{p}}$ represents the shearing of cell walls at the perimeter of probes, then changes in $\mathrm{K}_{\mathrm{p}}$ should directly relate to the amount and composition of walls bisected by the perimeter. Thus, $\mathrm{K}_{\mathrm{p}}$ should be anticipated to decline as cell enlargement results in a reduction in the number of cell walls bisected by a transect of fixed length (i.e., a fixed length around the perimeter of the probe). While, there was a profound increase in cell volume up to 120 DAFB (Fig. 1B), $K_{\mathrm{p}}$ increased rather than decreased (Fig.

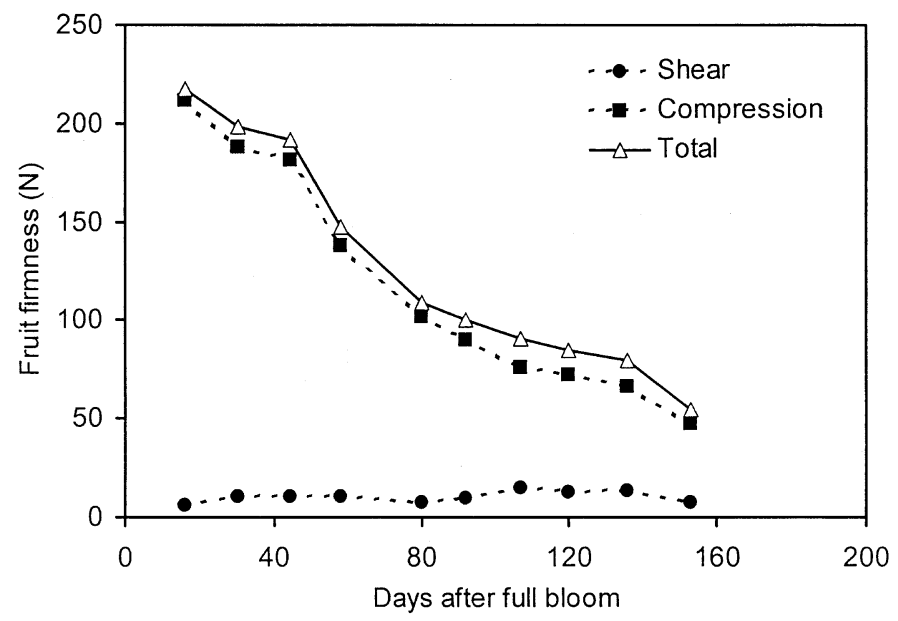

Fig. 5. Estimated shear and compression forces and total fracture force during fruit development for an 11.1-mm-diameter probe for 'Gala' apple (2000).
5). This suggests that the structure and composition of the cell wall is changing during this period of fruit development (Fischer and Amado, 1994; Nelmes and Preston, 1968), and more than compensates for reduction in the number of walls cleaved at the edge of the probe.

$\mathrm{K}_{\mathrm{a}}$, which contributed most to the puncture force, declined continuously and predictably throughout development, with greater change occurring early compared with later in the season (Fig. 4A). Tissue failure during puncture testing is most likely to occur by rupture when cell wall stress becomes too high (Pitt, 1982). Cells rupture progressively so that a hemispherical cap of squashed cells is pushed through the tissue ahead of the probe (Roudot et al., 1990). In this way puncture failure differs from that observed during compression of excised tissue apple plugs, which fail about half way along the plug producing a fracture that is $90^{\circ}$ or $45^{\circ}$ to the uniaxial force (e.g., Lin and Pitt, 1986).

Strong to moderate associations were found between seasonal changes in $\mathrm{K}_{\mathrm{a}}$ and cortical tissue anatomy, supporting the contention that the compressive strength of apple tissue is generally related to changes in cell packing. Vincent (1989) found that torsional stiffness of tissue from mature and stored apples was related to tissue density and his associated calculations of cellto-cell contact area. We speculate therefore that fruit growth and the decline in tissue strength are inversely related, the latter controlled by the same physiological processes that result in fruit expansion. Exceptions to these relationships (Fig. 6) suggest that other physiological factors occurring in early development may modify the dependence of $\mathrm{K}_{\mathrm{a}}$ on these characteristics.

Calculation of puncture force for an 11.1-mm-diameter probe using $\mathrm{K}_{\mathrm{a}}$ and $\mathrm{K}_{\mathrm{p}}$ (Fig. 5) allows the changes in apple texture to be viewed from an applied perspective. First, it demonstrates that the probe diameter selected for commercial puncture tests emphasises the $\mathrm{K}_{\mathrm{a}}$ component of tissue strength at the expense of $\mathrm{K}_{\mathrm{p}}$ (see also Bourne 1966; 1975). Second, it highlights that firmness at harvest is only a fraction of the value obtained at fruit set. Apple firmness at harvest may well be predicted on the basis of knowledge of initial firmness at anthesis and the rate of softening during fruit development. Moreover, monitoring of firmness throughout the season may forewarn industry of potential texture problems in the crop, and allow early interventions to commercial protocols and procedures.

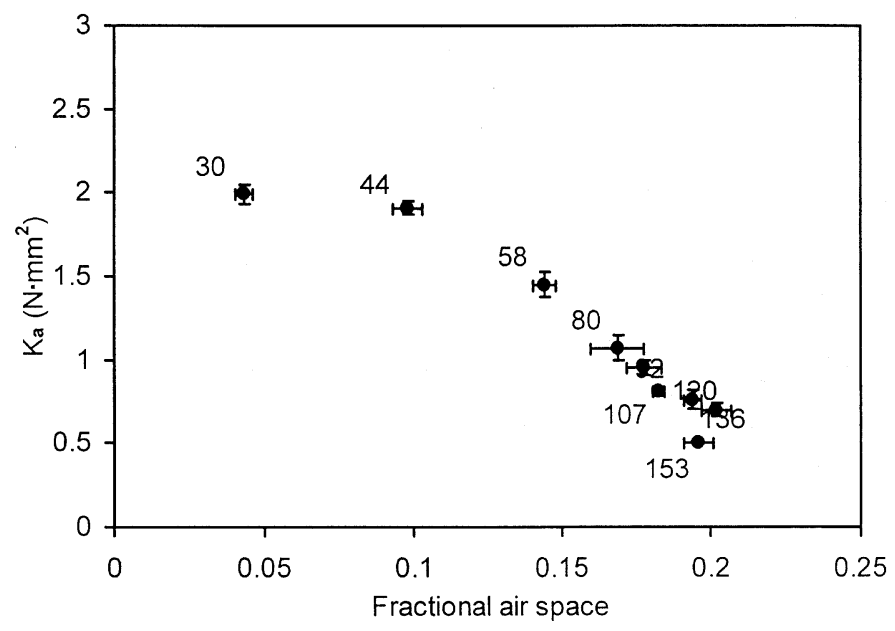

Fig. 6. Relationship between fractional air space and $\mathrm{K}_{\mathrm{a}}$ (area-dependent coefficient) during fruit development for 'Gala' apple (2000). Values refer to DAFB for each point. Bars $= \pm$ standard error. 
In conclusion, we have shown that apple fruit firmness decline begins immediately after anthesis and continues progressively throughout fruit development. Changes in probe area-related strength of the cortex contributed much to developmental changes in firmness for an $11.1 \mathrm{~mm}$ probe, with such changes generally related to concurrent anatomical development in the cortical tissue. Probe perimeter-related tissue strength showed a different pattern of change during fruit development, made only a small contribution to tissue firmness and was not related to changes in cortex tissue anatomy.

\section{Literature Cited}

Abbott, J.A., A.E. Watada, and D.R. Massie. 1982. Using a computer with an Instron for horticultural texture measurements. J. Texture Studies 13:413-422.

Abbott, J.A., A.E. Watada, and D.R. Massie. 1984. Sensory and instrumental measurement of apple texture. J. Amer. Soc. Hort. Sci. 109: 221-228.

Bain, J.M. and R.N. Robertson. 1951. The physiology of growth of apple fruits. I Cell size, cell number and fruit development. Austral. J. Sci. Res. B. 4:75-91.

Bollard, E.G. 1970. The physiology and nutrition of developing fruits, p. 387-425. In: A.C.Hulme (ed.). The biochemistry of fruits and their products. vol. I. Academic Press, London.

Bourne, M.C. 1965. Studies on punch testing of apples. Food Technol. 19: 413-415.

Bourne, M.C. 1966. Measure of compression and shear components of puncture tests. J. Food Sci. 31:282-291.

Bourne, M.C. 1975. Method of obtaining compression and shear coefficients of foods using cylindrical punches. J. Texture Studies 5: 459-469.

Daillant-Spinnler, B., H.J.H. MacFie, P. Beyts, and D. Hedderley. 1996. Relationships between perceived sensory properties and major preference directions of 12 varieties of apples from the southern hemisphere. Food Qual. Preference 7:113-126.

De Belie, N., I.C. Hallett, F.R. Harker, and J. De Baerdemaeker. 2000. Influence of ripening and turgor on tensile properties of pears: a microscopic study of cellular and tissue changes. J. Amer. Soc. Hort. Sci. 125:350-356.

DeEll, J.R., S. Khanizadeh, F. Saad, and D. Ferree. 2001. Factors affecting apple fruit firmness-A review. J. Amer. Pomol. Soc. 55:8-27.

Drazeta, L. 2002. Structure, function and quality development in apples. PhD diss. Massey Univ., Palmerston North, N.Z.

Fischer, M. and R. Amado. 1994. Changes in the pectic substances of apples during development and postharvest ripening. Part 1: Analysis of the alcohol-insoluble residue. Carb. Poly. 25:161-166.

Goffinet, M.C., T.L. Robinson, and A.N. Lakso. 1995. A comparison of 'Empire' apple fruit size and anatomy in unthinned and hand-thinned trees. J. Hort. Sci. 70:375-387.

Harker, F.R. and I.B. Ferguson. 1988. Transport of calcium across cuticles isolated from apple fruit. Scientia Hort. 36:205-217.

Harker, F.R., R.J. Redgwell, I.C. Hallett, S. Murray, and G. Carter 1997. Texture of fresh fruit. Hort. Rev. 20:212-224.
Harker, F.R., R. Volz, J.W. Johnston, I.C. Hallett, and N. De Belie. 2000. What makes fruit firm and how to keep it that way. Proc. $16^{\text {th }}$ Annu. Wash. Postharvest Con., Yakima, Wash., USA. <http://postharvest.tfr ec.wsu.edu/pgDisplay.php?article $=$ PC2000BB $>$

Harker, F.R., F.A. Gunson, P.L. Brookfield, and A. White. 2002a. An apple a day: The influence of memory on consumer judgment of quality. Food Qual. Preference 13:173-179.

Harker, F.R., J. Maindonald, S.H. Murray, F.A. Gunson, I.C. Hallett, and S.B. Walker. 2002b. Sensory interpretation of instrumental measurements 1: Texture of apple fruit. Postharvest. Biol. Technol. 24: 225-239.

Jaeger, S.R., Z. Andani, I.N. Wakeling, and H.J.H. MacFie. 1998. Consumer preferences for fresh and aged apples: a cross-cultural comparison. Food Qual. Preference 9:355-366.

King, G.L., J.R. Lynn, C.J. Dover, K.M. Evans, and G.B. Seymour. 2001. Resolution of quantitative trait loci for mechanical measures accounting for genetic variation in fruit texture of apple (Malus pumila Mill.) Theor. Appl. Genet. 1227-1235.

Knee, M. and S.M. Smith. 1989. Variation in quality of apple fruits stored after harvest on different dates. J. Hort. Sci. 64:413-419.

Lakso, A.N., L. Corelli Grappadelli, J. Barnard, and M.C. Goffinet. 1995. An expolinear model of the growth pattern of the apple fruit. J. Hort. Sci. 70:389-394.

Lau, O.L. 1985. Harvest indices for B.C. apples. B.C. Orchardist 7: $1 \mathrm{~A}-20 \mathrm{~A}$.

Lin, T. and R.E. Pitt. 1986. Rheology of apple and potato tissue as affected by cell turgor pressure. J. Texture Studies 17: 291-313.

Liu, F.W. and M.M. King. 1978. Consumer evaluations of 'McIntosh' apple firmness. HortScience 13:162-163.

Nelmes, B.J. and R.D. Preston. 1968. Wall development in apple fruits: a study of the life history of a parenchyma cell. J. Expt. Bot. 19: 496-518.

Pitt, R.E. 1982. Models for the rheology and statistical strength of uniformly stressed vegetative tissue. Trans. Amer. Soc. Agr. Eng. 25: 1776-1784.

Pratt, C. 1988. Apple trees. Morphology and anatomy. Hort. Rev. 12: 265-305.

Roudot, A.-C., F. Duprat, and E. Pietri. 1990. Simulation of a penetromic test on apples using Voronoi-Delaunay tessellation. Food Structure 9: 215-222.

Sams, C.E. 1999. Preharvest factors affecting postharvest texture. Postharvest Biol. Technol. 15:249-254.

Smith, W.H. 1951. Cell multiplication and cell enlargement in the development of the flesh of the apple fruit. Ann. Bot. 14:23-28.

Skene, D.S. 1966. The distribution of growth and cell division in the fruit of Cox's Orange Pippin. Ann. Bot. 30, 119:493-511.

Vincent, J.F.V. 1989. Relationship between density and stiffness of apple flesh. J. Sci. Food Agr. 47:443-462.

Vincent, J.F.V. 1990. Fracture properties of plants. Adv. Bot. Res. 17: 235-287.

Watkins, C., R. Harker, P. Brookfield, and S. Tustin. 1993. Maturity of 'Royal Gala', 'Braeburn' and 'Fuji'-The New Zealand experience. Proc. 9th Annu. Wash. Tree Fruit Postharvest Conf., Wash. p. 16-19.

Weibel, E.R. 1980. Stereological methods. vol. 2. Theoretical foundations. Academic Press, London. 